\title{
Online Lectures Using the WhatsApp Application: Advantages and Obstacles
}

\author{
Roby Zulkarnain Noer ${ }^{1, *}$ Rani Febriyanti ${ }^{2}$
}

\author{
${ }^{1}$ Universitas Borneo Tarakan \\ ${ }^{2}$ Universitas Negeri Yogyakarta \\ ${ }^{*}$ Corresponding author. Email: robyznoer@gmail.com
}

\begin{abstract}
The purpose of this study was to describe the perceptions of pre-service teachers about online learning through the WhatsApp application. Descriptive qualitative methods were used by using a questionnaire and interview instruments. The questionnaire was given to 74 Elementary School Teacher Education (PGSD) students in the semester 5 of 2020/2021. To find out the validity of the data, 5 pre-service teachers were triangulated by conducting in-depth interviews. The analysis technique used is data condensation, presenting data, and drawing conclusions. The WhatsApp platform was found to be the best program to use in online learning on the basis od the study learning. Based on the research results, it was found that the WhatsApp application is the easiest application to use in online learning. The advantages felt by pre-service teachers when learning using the WhatsApp application include learning to be more flexible, increasing self-confidence, being able to hone skills in making technology-based learning media, and being able to obtain information easily and from various sources. Meanwhile, the obstacles felt by pre-service teachers included a lack of concentration in learning, constrained by an unstable network, difficulties in conducting discussions with groups, and difficulty understanding the material as a whole. In the online learning process, the findings of this study can be useful as a assessment, particularly for educator ca be achieveded.
\end{abstract}

Keywords: Online learning, WhatsApp application, advantages, obstacles.

\section{INTRODUCTION}

The conditions of the Covid-19 pandemic that occurred at the beginning of 2020 resulted in changes in all areas of life, including education. The learning process, which is usually carried out face-to-face in the classroom, is transformed into distance learning or mode learning in a full network (online) or full online [1]. The Indonesian government takes various measures to prevent the transmission of the corona virus with social restrictions and distance guarding, so that through the ministry of Education and Culture, changes are made in the learning process for all levels of education from basic education to higher education [2].

The online lecture system in higher education is a familiar thing for lecturers in Indonesia. However, online learning that utilizes the internet and does not require the presence of lecturers who integrate face to face with each other is still not carried out smoothly at the University of
Borneo Tarakan (UBT). This is a dilemma because ultimately the university is "forced" to carry out online learning during the Covid-19 pandemic for an undetermined time limit. Online learning at the University of Borneo Tarakan (UBT) which is in the border area is a challenge for lecturers so that an Academic Notification Letter was issued by the Vice Chancellor for Academic Affairs number 594 / UN51 / TU / 2020 which states that academic activities are carried out online using various applications that do not burden students and keep paying attention learning outcomes.

Based on the decree, the WhatsApp platform is mostly used by lecturers at the University of Borneo Tarakan. This is because the WhatsApp application can be downloaded for free and only requires a smartphone that is owned by all students so that students can easily follow the learning process online [3]. The operation of 
the WhatsApp application is easy and simple, the process is fast and uses low costs, making the WhatsApp application widely used in online learning [4]-[6]. The Whatsapp application is also widely used because it can create group chats, emoticons, voice messages, phone calls, and can share locations with each other [7]. In addition, Baishya \& Maheshwari (2020) also stated that the WhatsApp group is a forum that can be used in the learning process to be able to exchange information, interact and discuss the material being taught. Because of this convenience, the WhatsApp application is widely used by educators in helping the learning process online.

However, apart from the convenience obtained from the WhatsApp application, overall the WhatsApp application does not support learning when it requires direct feedback, practicum, or field lectures. In addition, when compared to video conferencing applications such as zoom and google meet, WhatsApp applications are still limited by the number of participants who can take part in video calls. One of the less optimal subjects in learning using Whatsapp is the Children with Special Needs (CSN) course. Students still need guidance outside the scheduled lecture hours. The material that is extensive and requires practice requires students to always communicate with lecturers. This results in online learning using the WhatsApp application which is still not optimal. Based on these problems, the purpose and urgency of this study are as an evaluation material for online learning using the WhatsApp application, what are the students' perceptions regarding online learning using WhatsApp, both the benefits obtained and the obstacles in implementing online learning.

\section{METHODS}

Descriptive qualitative analysis is the research approach employed. Descriptive qualitative research is used to describe how prospective teachers' perceptions of online learning using the WhatsApp application in Children with Special Needs subject. The data collection techniques used were questionnaires and interviews, while the instruments used were questionnaires and interview sheets. The questionnaire was given to 74 students in semester 6 of the 2020/2021 academic year of the Elementary School Teacher Education Department (PGSD) at the University of Borneo Tarakan (UBT). Based on the questionnaire, 5 students were randomly selected to conduct interviews on perceptions related to online learning using the WhatsApp application. So that source triangulation is used in this study to obtain more in-depth data through in-depth interviews. Due to limited conditions, data collection was carried out online using the help of a google form. The data analysis techniques used were condensing data, presenting data, and drawing conclusions [8]. The questionnaire was analyzed using quantitative, while the results of the interview were analyzed qualitatively.

\section{RESULTS AND DISCUSSION}

The research conducted was to determine students' perceptions regarding online learning using the WhatsApp application. The use of the WhatsApp application is carried out by making a learning plan in advance and creating a group on the WhatsApp application between lecturers and students [9]. Before being given a questionnaire, students carry out online learning for 2 months in the Children with Special Needs (CSN) course. Students conduct online learning using cooperative learning methods. Like face-to-face learning, students are initially formed into several groups, then each group gets different material and makes presentations in turns together with their respective groups. The difference is that the presentation process is carried out online using the WhatsApp application. In the WhatsApp application, there are features that can be used to help the online learning process. Features that can be used include text, images, video, voice, video calls, and can even exchange files such as word, pdf, PowerPoint (PPT), and other supported files. So that through the WhatsApp application, students can carry out discussions and share information using the available features.

After learning has been carried out for 8 meetings, 74 6th semester students in the 2020/2021 school year PGSD UBT Department were given a questionnaire via a google form. Of the 74 students, 58 were women and 16 were students. The following are the results of the questionnaire which can be seen in table 1 .

Table 1. Questionnaire Results for Student Perceptions Related to Online Learning

\begin{tabular}{|c|c|c|c|}
\hline & Survey Questions & Percentage & Mostly Checked Item \\
\hline \multicolumn{4}{|c|}{ Learning Process } \\
\hline 1. & $\begin{array}{l}\text { How well do lecturers deliver the subjects of CSN online through } \\
\text { the Whatsapp Platform? }\end{array}$ & $78,9 \%$ - Good & $\begin{array}{l}\text { Lecturers teach online learning } \\
\text { well }\end{array}$ \\
\hline 2. & $\begin{array}{l}\text { How good is the quality of online lecture material (info graphics, } \\
\text { pictures, animations, videos, etc.) from lecturers through the } \\
\text { Whatsapp Platform? }\end{array}$ & $\begin{array}{l}63,5 \%- \\
\text { Good }\end{array}$ & $\begin{array}{l}\text { quality of the presentation of } \\
\text { the material is good }\end{array}$ \\
\hline
\end{tabular}




\begin{tabular}{|c|c|c|c|}
\hline 3. & $\begin{array}{l}\text { How good is your group presentation using the Whatsapp } \\
\text { Platform? }\end{array}$ & $63,5 \%-$ Good & $\begin{array}{l}\text { The presentation activities went } \\
\text { well }\end{array}$ \\
\hline 4. & $\begin{array}{l}\text { How well do you understand the material, especially the subject of } \\
\text { Children with Special Needs through the Whatsapp Platform? }\end{array}$ & $\begin{array}{l}51.9 \%- \\
\text { Sufficient }\end{array}$ & $\begin{array}{l}\text { understanding of the material } \\
\text { being taught }\end{array}$ \\
\hline 5. & $\begin{array}{l}\text { How well do you actively conduct discussions/questions and } \\
\text { answers when learning Online through the Whatsapp Platform? }\end{array}$ & $\begin{array}{l}50 \%- \\
\text { Sufficient }\end{array}$ & $\begin{array}{c}\text { Active enough to carry out } \\
\text { question and answer } \\
\text { discussions }\end{array}$ \\
\hline \multicolumn{4}{|c|}{ Ease to use } \\
\hline 6. & Is the Whatsapp Platform easy to use in the online learning process? & $66,2 \%-$ Good & Easy to use in online learning \\
\hline 7. & $\begin{array}{l}\text { Is the Whatsapp platform easy to use in exchanging information (in } \\
\text { the form of the word, PPT, excel, video, pictures, etc.)? }\end{array}$ & $69,5 \%-$ Good & Easy to exchange information \\
\hline 8. & $\begin{array}{l}\text { Is the Whatsapp platform easy to use when doing group } \\
\text { presentations? }\end{array}$ & $\begin{array}{l}59,7 \%- \\
\text { Sufficient }\end{array}$ & $\begin{array}{l}\text { Easy enough to use for group } \\
\text { presentations }\end{array}$ \\
\hline 9. & $\begin{array}{l}\text { Is the WhatsApp platform easy to use for discussions/questions and } \\
\text { answers related to learning materials? }\end{array}$ & $62,2 \%-$ Good & $\begin{array}{l}\text { Easy to use for discussion and } \\
\text { question and answer }\end{array}$ \\
\hline
\end{tabular}

Based on table 1 above, it can be seen that the WhatsApp application is used for aspects of the online leasning process. The online learning process using the WhatsApp application is in the good category with an average percentage of $61.6 \%$, while in the aspect of ease of use it gets an average percentage of $64.4 \%$ with a good category. This is in line with research of Awada (2016) that through the WhatsApp application, students can easily exchange information, answer questions quickly, build knowledge and increase student participation through exchanging messages on the WhatsApp group. However, there is a need for a facilitator's role, namely educators to provide learning directions to the WhatsApp group so that the presence of lecturers is needed in online learning using the WhatsApp group [10].

Then, after being given a questionnaire via a google form, 5 students were randomly selected to be given indepth interviews to find out more details regarding information about online learning using the WhatsApp application. In-depth interview questions are given to students via a google form, this is due to the limitations of pandemic conditions that cannot be done directly with students. Based on the results of in-depth interviews, there are advantages and obstacles that are felt by students.

Subject 1 stated that online learning using the WhatsApp application still cannot be said to be effective because the material in the Children with Special Needs course requires direct practice in the field in order to obtain real information and experiences. However, during online learning, subject 1 gained a lot of information and experiences related to making learning media through electronic media such as making learning videos, designing PowerPoint (PPT), and others. Meanwhile, the obstacle he felt during the online learning process was that sometimes the internet network was intermittent so that I was late in taking lessons because I had to download the media shared by the presenter. In addition, I sometimes find it difficult to understand the material presented by the presenter properly because it lacks focus and unclear explanations.

Subject 2 stated that it was almost the same as subject 1 where according to subject 2 , online learning still could not be said to be not optimal and effective because learning for Children with Special Needs would be maximized and better understood if students practiced directly into the field to see directly the situation and conditions field. However, due to the conditions of the Covid-19 pandemic that were not possible, learning had to be carried out online. The benefits that he feels during online learning are that the time used is more flexible, saves on transportation costs, and is more able to take advantage of the use of technology. This is in line with his opinion. Meanwhile, the obstacle that he feels is that the material presented is still not maximal so that it is not understood, the internet network is sometimes disrupted and power cuts occur unexpectedly.

Subject 3 stated that online learning using the WhatsApp application was effective. However, it depends on the presenter or teacher who delivers the material. Especially if the material is given in various forms such as PowerPoint, pictures, or videos so that when there is a material that I don't understand, I can easily reopen the material that has been distributed. The benefits that are felt during online learning are that it can add useful knowledge, the material can be easily accessed anywhere and anytime. Meanwhile, the obstacles in the implementation of online learning are that sometimes some of the material provided cannot be understood and a large number of assignments are given with a short time limit. 
Subject 4 stated that online learning can be said to be effective if it is packaged properly. Although the Children with Special Needs (CSN) course should be more effective if the learning is done directly and goes to the field to see the conditions of Children with Special Needs (CSN). The benefits felt by subject 2 were increasing self-confidence in terms of questions and answers between lecturers and students or between students. According to him, through online learning, he becomes more courageous and confident than during face-to-face learning. Meanwhile, the obstacle that he felt was that some of the material presented was difficult to understand and the piles of assignments given by the lecturers were due to the large number of assignments given. In addition, he added that sometimes the group discussion process that was carried out did not go well because of the difficulty of communicating and unifying opinions between group members. So that it caused some debate during the discussion.

Subject 5 states that the use of the WhatsApp application is more effective in online learning and the current pandemic situation than the zoom application. The benefits of online learning according to subject 5 are preventing the spread of Covid-19, obtaining knowledge and information related to Children with Special Needs (CSN) through exposure to each group, and gaining new experiences as well as challenges in providing effective teaching methods. While the obstacle he feels is that sometimes it is difficult to understand the material presented because subject 5 is easier to receive information if it is explained directly rather than through writing and online.

Based on the description above, it can be seen that students describe the strengths and obstacles they feel while participating in online learning using the WhatsApp application. This is in line with research of Kee (2020) which also states that online learning using WhatsApp can trigger student involvement, even students who initially lack confidence will become more productive and more vocal when learning using WhatsApp than when learning face-to-face in the classroom. This is because WhatsApp can provide democratic expression through information retrieval, information sharing, and critical questions. Barhoumi (2020) also reveals that learning with WhatsApp can improve communication between students so as to encourage students to be more productive and active in learning [11]-[13]. In addition, the WhatsApp application makes it easy to share learning materials, access materials, and facilitate interaction between students and with facilitators [14].

The WhatsApp application is also equipped with various features that can support the learning process online such as text, group chats, photos and videos, voice messages, documents such as words, PDFs, spreadsheets, and slideshows [15], emoticons, group video calls, and can share locations [7]. The integration of video, images, audio, and podcasts in the WhatsApp group will help in the learning process online [16]. So that through the existing features of the WhatsApp application, it allows a reciprocal relationship between lecturers and students [1], can change the learning process that was originally formal to be more social and open [14], and can be carry out in many place [18]. The use of the WhatsApp application can develop technological skills, proficiency, develop student collaboration, and has the possibility to improve student learning outcomes [16], [19], [20]. Furthermore, the WhatsApp application is commonly used in online learning throught simple WhatsApp operations, fast processes and lower costs [5], [6].

In addition, the implementation of online learning also contains obstacles, such as the sometimes unstable internet connection. Some students may not be able to participate in online learning smoothly, this is due to the unavailability of a proper internet connection. So that they do not take part in direct learning and reply to conversations during online learning using the WhatsApp application [9]. This happened to some PGSD UBT students because the sometimes unstable internet network resulted in students being late and unable to take online learning on time.

The use of the WhatsApp application is very easy and simple to use in online learning even though in its implementation there are still some obstacles that occur. However, lecturers can carry out variations in learning by using various other media besides WhatsApp in the online learning process that are not yet available on the WhatsApp application. Apart from its advantages and disadvantages, the WhatsApp application remains one of the applications that many educators use in the learning process as an easy tool to interact with students.

\section{CONCLUSIONS}

Based on the research results, the WhatsApp application is one of the applications that are easy to use in online learning. The advantages of online learning using the WhatsApp application that are felt by students are learning to be more flexible, increasing student confidence, being able to hone skills in making technology-based learning media, and being able to obtain information easily from various sources. Meanwhile, the obstacles felt by students were lack of focus in learning, sometimes unstable internet networks, difficulty in discussing with groups, and difficulty understanding the material as a whole.

This research is limited to semester 6 students and students who only take special needs children courses so that further research is recommended to obtain data from all levels to see the effectiveness of WhatsApp applications in online learning. The results of this study are used as an online evaluation of learning, especially 
for educators so that they can determine the right formulation to achieve predetermined learning objectives.

\section{REFERENCES}

[1] A. Naciri, M. A. Baba, A. Achbani, and A. Kharbach, "Mobile Learning in Higher Education: Unavoidable Alternative during COVID-19," Aquademia, vol. 4, no. 1, p. ep20016, 2020.

[2] Gunawan, N. M. Y. Suranti, and Fathoroni, "Variations of Models and Learning Platforms for Prospective Teachers During the COVID-19 Pandemic Period," Indones. J. Teach. Educ., vol. 1, no. 2, pp. 61-70, 2020.

[3] G. Awada, "Effect of whatsapp on critique writing proficiency and perceptions toward learning," Cogent Educ., vol. 3, no. 1, pp. 1-25, 2016.

[4] Y. Tang and K. F. Hew, "Is mobile instant messaging (MIM) useful in education? Examining its technological, pedagogical, and social affordances," Educ. Res. Rev., vol. 21, no. Mim, pp. 85-104, 2017.

[5] D. Baishya and S. Maheshwari, "Whatsapp groups in academic context: Exploring the academic uses of whatsapp groups among the students," Contemp. Educ. Technol., vol. 11, no. 1, pp. 31-46, 2020.

[6] D. Bouhnik and M. Deshen, "WhatsApp Goes to School: Mobile Instant Messaging between Teachers and Students," J. Inf. Technol. Educ. Res., vol. 13, pp. 217-231, 2014.

[7] S. Udenze and B. Oshionebo, "Investigating 'Whatsapp' for collaborative learning among undergraduates," Üsküdar Üniversitesi İletişim Fakültesi Akad. Derg. Etkileşim, vol. 5, pp. 2450, 2020.

[8] M. B. Miles, A. M. Huberman, and J. Saldana, Qualitative Data Analysis, A Methods Sourcebook, 3rd Editio. USA: Sage Publications, 2014.

[9] I. P. Widyanto, A. Slamet, M. Haryono, and T. Prihatin, "The Utilization of Whatsapp Application on Scientific-Based Learning Management in Higher Education Institutions," vol. 247, no. Iset, pp. 241-245, 2018.

[10] C. L. Kee, "Face-to-Face Tutorials, Learning Management System and WhatsApp Group: How Digital Immigrants Interact and Engage in E-learning?," Malaysian Online J. Educ. Technol., vol. 8, no. 1, pp. 18-35, 2020.

[11] C. Barhoumi, "The Effectiveness of WhatsApp Mobile Learning Activities Guided by Activty Theory on Students' Knowldege Management," Contemp. Educ. Technol., vol. 6, no. 3, pp. 221238, 2020.
[12] P. Rambe and C. Chipunza, "Using mobile devices to leverage student access to collaboratively-generated resources: A case of WhatsApp instant messaging at a South African University," Br. J. Educ. Technol., vol. 44, pp. 544-561, 2013.

[13] I. T. Agustin Mawarni, N. Ratnasari, A. N. Handayani, M. Muladi, E. P. Aji Wibowo, and R. Sri Untari, "Effectiveness of whatsapp in improving student learning interests during the covid-19 pandemic," 4th Int. Conf. Vocat. Educ. Training, ICOVET 2020, pp. 248-252, 2020.

[14] S. Gon and A. Rawekar, "Effectivity of ELearning through Whatsapp as a Teaching Learning Tool," MVP J. Med. Sci., vol. 4, no. 1, pp. 19-25, 2017.

[15] W. K. Koomson, "Mobile learning: Application of WhatsApp messenger as a learning tool in a university distance learning program in Ghana," Proc. 15th Int. Conf. Cogn. Explor. Learn. Digit. Age, CELDA 2018, pp. 45-52, 2018.

[16] U. Rahaded, E. Puspitasari, and D. Hidayati, "The Impact of Whatsapp Toward UAD Undergraduate Students' Behavior in Learning Process," Int. J. Educ. Manag. Innov., vol. 1, no. 1, p. $55,2020$.

[17] C. B. Mpungose, "Is Moodle or WhatsApp the preferred e-learning platform at a South African university? First-year students' experiences," Educ. Inf. Technol., vol. 25, no. 2, pp. 927-941, 2020.

[18] H. Ryu and D. Parsons, "Risky business or sharing the load? - Social flow in collaborative mobile learning," Comput. Educ., vol. 58, no. 2, pp. 707-720, 2012.

[19] L. Cetinkaya, "The impact of whatsapp use on success in education process," Int. Rev. Res. Open Distance Learn., vol. 18, no. 7, pp. 59-74, 2017.

[20] H. Robles, J. Guerrero, H. Llinás, and P. Montero, "Online teacher-students interactions using Whatsapp in a law course," J. Inf. Technol. Educ. Res., vol. 18, pp. 231-252, 2019. 